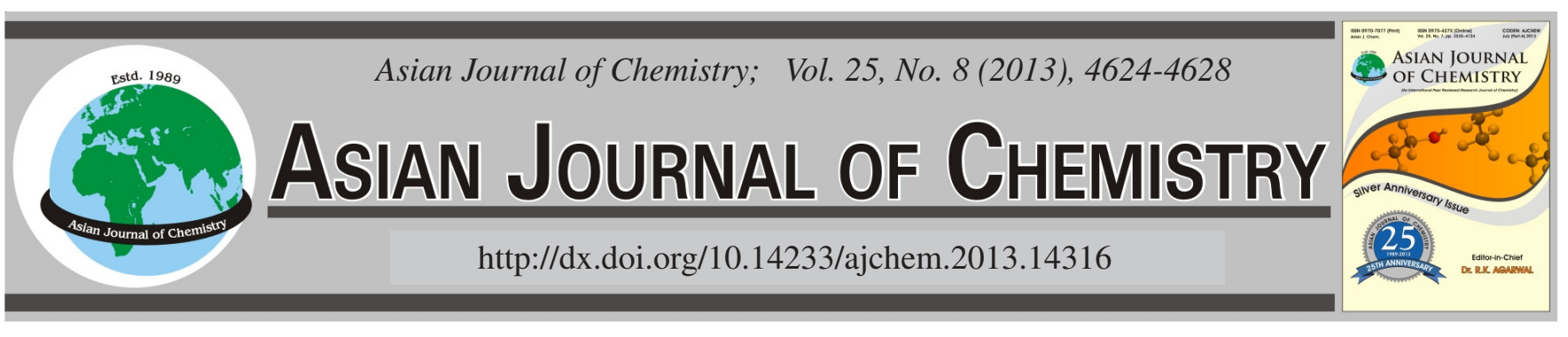

\title{
Effect of Various Catalysts on Biodiesel Production from Biomass of Freshwater Algae
}

Faroog Ahmad ${ }^{*}$, Amin U. Khan and Abdullah Yasar

Sustainable Development Study Centre, Government College University, Lahore, Pakistan

*Corresponding author: E-mail: fagondal82@yahoo.com

(Received: 16 July 2012;

Accepted: 18 February 2013)

AJC-13027

\begin{abstract}
Catalyst selection for transesterification of oil to biodiesel depends on composition of oil and its source. Algal biomass is a cheaper and effective source for this purpose. Chlorella vulgaris, Rhizoclonium hieroglyphicum and mixed algae culture (Microspora sp., Navicula sp., Lyngbya sp., Cladophora sp., Spirogyra sp. and Rhizoclonium sp.) were selected for current study. Several variables such as solvent types (acetone, hexane and methanol), extraction time (60-300 min), molar ratio (1:1, 3:1 and 6:1), catalyst types $(\mathrm{Na}, \mathrm{NaOH}, \mathrm{KOH}$ and $\left.\mathrm{H}_{2} \mathrm{SO}_{4}\right)$, catalyst concentration $(0.5,1.0$ and $1.5 \%)$ and transesterification reaction time (20-100 min) were used for extraction of oil and biodiesel production. Highest quantity of oil was extracted using hexane as a solvent while highest biodiesel yield (93.93\%) was obtained from transesterification of Chlorella vulgaris oil under 3:1 alcohol to oil molar ratio, Na catalyst (1\%) and $1 \mathrm{~h}$ of reaction time. The work investigated that biodiesel properties are comparable to ASTM standards hence it can be used as vehicular fuel.
\end{abstract}

Key Words: Algae, Biodiesel, Transesterification, Catalyst, Biomass, Chlorella, Rhizoclonium.

\section{INTRODUCTION}

Transesterification of oils is not a new process, it was introduced in 1953. In 1900, a smaller engine was shown in an exposition at Paris which ran on peanut oil. In 1911, Diesel said that engines can be run on vegetable oil and it was used till 1920, after this the manufacturer designed petro-diesel engines but the energy crises of 1973 began discussion on mixing vegetable oil in petro-diesel. The three fatty acids present in oil are attached to glycerol are collectively called as triglycerides, which can be converted into biofuels ${ }^{1}$.

Biodiesel is a cleaner fuel produced from edible and non edible oils, grease and animal fats. Chemically biodiesel consist of fatty acid alkyl esters, it is produced by transesterification of oils and esterification of fatty acids. In transesterification process triglycerides are converted to fatty acids alkyl esters in the presence of short chain alcohols and acid or alkali catalyst with glycerol as a by product ${ }^{2}$. Biodiesel is commonly blended with petroleum but it can also be used in pure form. Blends are designated by $\mathrm{BXX}$, where $\mathrm{XX}$ is the proportion of biodiesel and conventional diesel fuel. For example, B20 means $20 \%$ of biodiesel and $80 \%$ of petro-diesel ${ }^{3}$. It can be used in existing diesel engines except in old engines where little modification is needed. It is a better lubricant and combusted completely as compared to diesel thus increasing the life of engines. Due to its low emissions it can be used in polluted cities with sensitive environment ${ }^{4}$.
The most abundant algal species that can be used for biodiesel production due to their high lipid contents belong to Cyanophyceae, Chlorophyceae, Bacillariophyceae and Chrysophyceae. These can be grown autotrophically as well as in heterotrophic mode ${ }^{5}$. Algae can be used as second generation feedstock for the production of different types of renewable biofuels. The algal biomass composed of carbohydrates, proteins and lipids ${ }^{6}$ and the lipid present in algal biomass can be processed to biodiesel ${ }^{7}$.

An important characteristic of algae for biodiesel production can be its total lipid content made up of triglycerides, type of lipid, chain length and its degree of unsaturation. The research work on biofuels were done in National Renewable Energy Laboratory from 1978 to 1996, focusing on high oil content algae grown in ponds utilizing waste $\mathrm{CO}_{2}$ produced from coal fired plants. Majority of selected species of algae in this program were belonging to green algae and diatoms ${ }^{8}$. Algae have the ability to grow in freshwater, wastewater and even in saline water. Most species of algae can grow at the sea, lakes, ponds and on lands not suitable for food ${ }^{9}$.

Various catalysts can be used for biodiesel production from oil, among these acid and base catalysts are commonly used. Transesterification is catalyzed by acids, alkalis and lipase enzymes. The catalysts are used to accelerate the reaction to the right side. The concentration of catalyst is directly related to the yield however in excess it promotes reverse reactions, while low catalyst concentration results in limited process 
evolution $^{10}$. Researchers have focused on different catalyst systems, different solvents and different acetyl acceptors for biodiesel production ${ }^{11}$. In the current study biodiesel was produced from biomass of freshwater algae consisting of various species. The main focus of the research work was to compare efficiency of various catalysts for transesterification of oil to biodiesel.

\section{EXPERIMENTAL}

Collection of algal biomass: Algal samples were collected from ponds of Department of Fisheries, Lahore and grown in transparent fiber glass ponds containing wastewater for one week. Pond water was filtered after each week to get biomass of algae. The harvested algal mass was dried in open sunlight followed by drying at $60^{\circ} \mathrm{C}$ for $4 \mathrm{~h}$ in an oven. Drying temperature is an important factor as the higher temperature decreases lipid yield therefore biomass dried at $60{ }^{\circ} \mathrm{C}$ gives best results ${ }^{12}$. At the end of the drying period, measured amount of biomass was used for biodiesel production.

Solvent extraction of oil from algae: Oil was extracted from algae separately using acetone, hexane and methanol as solvents. Solvent extraction is not only the main extraction method but it is also simple and inexpensive as compared to other methods used ${ }^{13}$. Three hundred milliliter of each solvent was used for $50 \mathrm{~g}$ of dried algae for the extraction of oil. Soxhlet extractor (UNE-EN 734-1, 2006) was used for extraction of oil from algal biomass. The extraction process was carried out for 1-5 h using $0.5 \mathrm{~L}$ round-bottomed glass flask. The extract was separated from solvent by distillation. The residual algal biomass was subjected to further extraction of oil with the addition of more solvent.

Preparation of potassium and sodium methoxide: Sodium metal, sodium hydroxide, potassium hydroxides and sulphuric acid were used as catalysts in this study. One gram of each catalyst $(\mathrm{Na}, \mathrm{NaOH}$ and $\mathrm{KOH}$ ) was dissolved in 10 $\mathrm{mL}$ methanol separately and stirred until the catalyst was dissolved in methanol. Since the methanol evaporates easily therefore the flask was covered with aluminium foil to avoid loss of methanol ${ }^{11}$.

Transesterification reaction using basic catalysts: The extracted oil after its filtration was heated at $50{ }^{\circ} \mathrm{C}$ on a water bath to dissolve coagulated oil. The heated oil assists the transesterification reaction to occur rapidly. Catalysts were used in various concentrations to carry out this reaction at $62{ }^{\circ} \mathrm{C}$ for 20-100 min with constant stirring at $110 \mathrm{rpm}$. After the completion of reaction it was cooled at room temperature and allowed to evaporate for $0.5 \mathrm{~h}$ to get rid of excess of methanol. The remaining product was allowed to settle down overnight and two distinct layers were separated by separating funnel. The upper liquid layer was washed with water to remove remaining methanol and catalysts. Excess of solvent was removed by distillation to get pure biodiesel ${ }^{14,15}$.

Transesterification reaction using acid catalyst: Acidic transesterification reaction was conducted in a flask containing oil, methanol and acid in a specific quantity. The reaction mixture was heated at $62{ }^{\circ} \mathrm{C}$ for $20-100$ min with constant stirring at $110 \mathrm{rpm}$. The upper methyl ester layer was separated by separating funnel and washed with petroleum ether and hot water $\left(50^{\circ} \mathrm{C}\right)$, respectively. Excess of ether was separated by distillation and biodiesel yield was measured ${ }^{16}$.

Properties of biodiesel: Properties of algal biodiesel (kinematic viscosity, flash point, specific gravity, cetain number, calorific value and water contents) were analyzed based on ASTM procedures ${ }^{17}$ while acid number was mesured by method advised oil, fats and waxes ${ }^{18}$. These fuel properties were compared with standards of biodiesel devised by ASTM.

\section{RESULTS AND DISCUSSION}

Algae can be cultivated in open ponds relying on natural light thus reducing the operational cost. Algal strains which can easily grow in open ponds are; Anabaena, Chlorella, Dunaliella, Haematococcus, Nostoc, Spirulina and fresh water macroalgae ${ }^{19}$. Ponds of various dimensions can be used for this purpose. In the current study fiber glass ponds of $0.3 \mathrm{~m} \times$ $0.3 \mathrm{~m} \times 0.15 \mathrm{~m}$ dimensions were used to grow Chlorella vulgaris, Rhizoclonium hieroglyphicum and mixed algae culture (Microspora sp., Navicula sp., Lyngbya sp., Cladophora sp., Spirogyra sp. and Rhizoclonium sp.) at lab scale. Maximum biomass productivity can be obtained in tropical and sub tropical condition $\mathrm{s}^{20}$. Evaporation of water and contamination with other strains of algae can be listed as disadvantages of open ponds ${ }^{21}$.

Oil extraction using different solvents: Oil extraction from algae biomass can be carried out by using various organic solvent such as benzene, cyclohexane, hexane, acetone and chloroform. Organic solvent are effective as these break down the cell walls of algae. In addition oil is highly soluble in these solvents $^{22}$. In this study acetone, hexane and methanol were used as solvents to compare their efficiencies. It was found from the results that more oil ( $22 \mathrm{~g} / 50 \mathrm{~g}$ of algal biomass) was extracted from Chlorella vulgaris using hexane as a solvent while the quantity of extracted oil from other algal species was also higher by hexane as compared to acetone and methanol. Methanol was found to be least efficient among the used solvents (Fig. 1). A good solvent should be reusable, cost effective with low boiling point (facilitate separation after extraction) and insoluble in water. Due to all these properties hexane was considered as suitable solvent for large scale extraction $^{23}$.

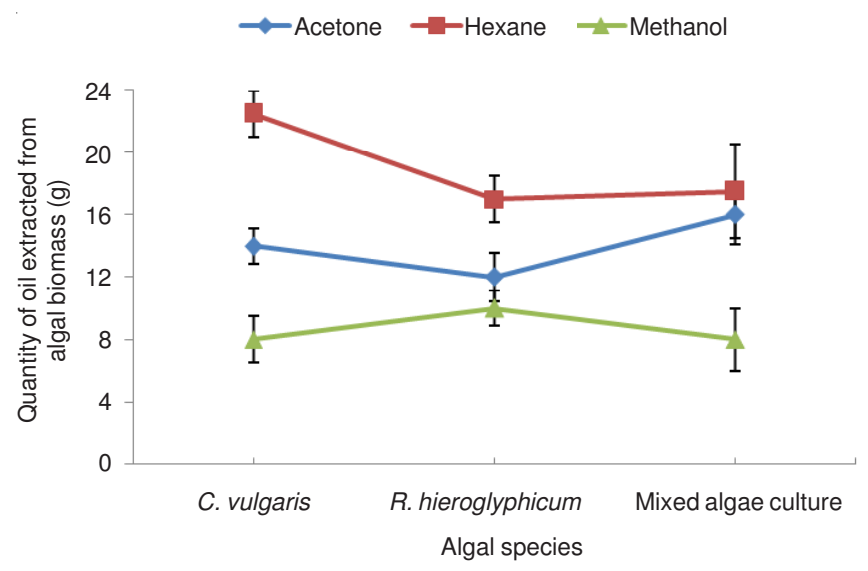

Fig. 1. Effect of solvent on oil extraction from C. vulgaris, R. hieroglyphicum and mixed algae culture 
Effect of time on oil extraction: Time has profound effect on extraction of oil or lipid from biomaterial. In this study oil was extracted from algal biomass using hexane as a solvent and it was observed that the quantity of oil was increased with increasing extraction time but it became constant after $4 \mathrm{~h}$ as algal biomass was become free of oil. Similar findings were observed with all the three types of algae (Fig. 2). Li et al. ${ }^{24}$ divided the ground algal biomass into 24 portions and extracted oil by giving $3,5,7,9,11,13,15$ and $26 \mathrm{~h}$ extraction time in Soxhlet apparatus with conclusion that maximum extraction of lipid was occurred at $5 \mathrm{~h}$.

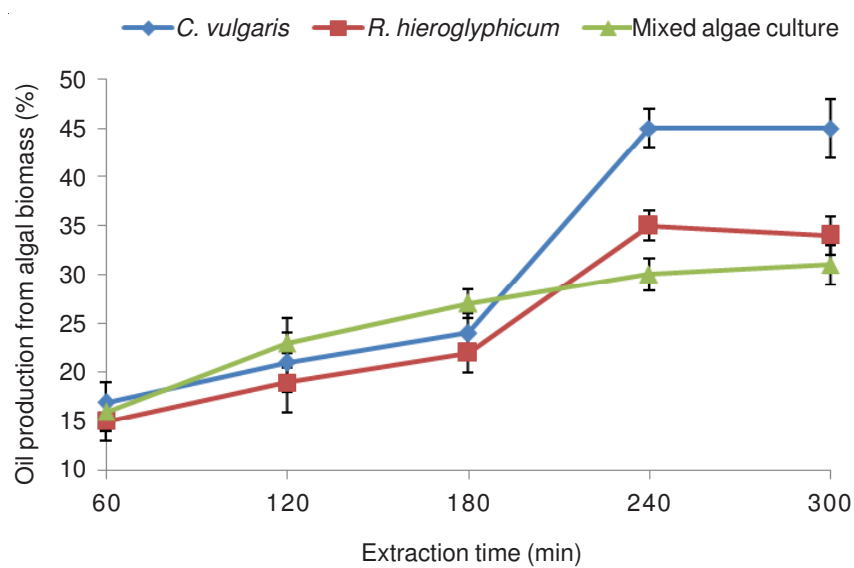

Fig. 2. Effect of extraction time on per cent oil production from C. vulgaris, $R$. hieroglyphicum and mixed algae culture

Biodiesel production from dried biomass of algae: In order to compare biodiesel yield of selected algal species, 100 $\mathrm{g}$ of dried algal biomass was used for oil extraction followed by transesterification reaction. Sodium metal was used as catalyst because its efficacy was proved to be higher than other catalysts (Fig. 5). Results shown in Fig. 3 indicated that biodiesel production from $C$. vulgaris biomass (40\%) was higher than R. hieroglyphicum (34\%) and mixed algae culture (32\%). Traces of water, catalyst and chlorophyll were removed before analysis of biodiesel to avoid error in results due to contamination $^{25}$.

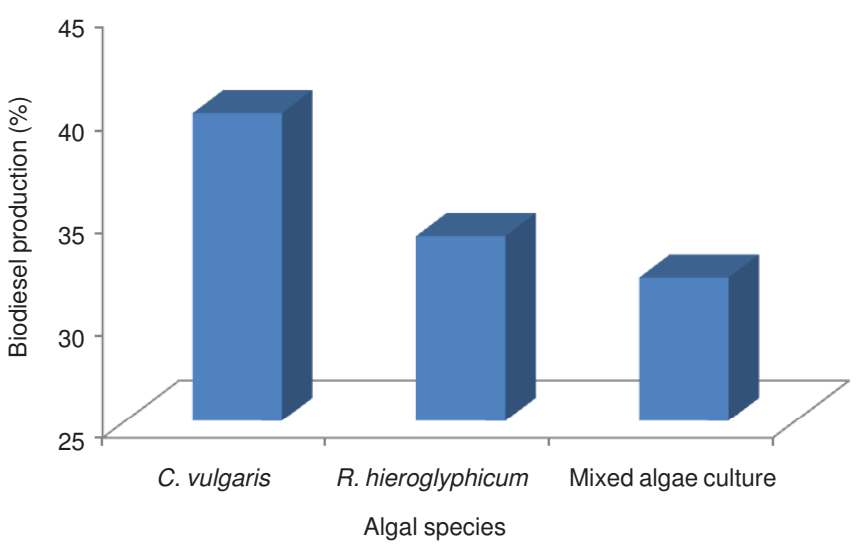

Fig. 3. Per cent biodiesel production from biomass of $C$. vulgaris, $R$. hieroglyphicum and mixed algae culture

Molar ratio of methanol to algal oil: One of the important variable which effects biodiesel yield is alcohol to oil molar ratio. In the current study methanol was mixed to algal oil for transesterification into methyl esters. Three different alcohol to oil molar ratios $(1: 1,3: 1$ and $6: 1)$ were prepared results showed that yield of methyl esters was almost same with 3:1 and 6:1 methanol to oil ratio but biodiesel yield was significantly lower with 1:1 methanol to oil ratio than formaly mentioned ratios (Fig. 4). In transesterification reactions $3 \mathrm{~mol}$ of alcohols are used for $1 \mathrm{~mol}$ of triglyceride to produce one mole of glycerol and three moles of biodiesel. In industrial processes higher molar ratio is used to accelerate the reaction and to avoid reverse reaction ${ }^{26}$. However, a high molar ratio of alcohol to oil interferes in the separation of glycerin because there is an increase of solubility ${ }^{27}$.

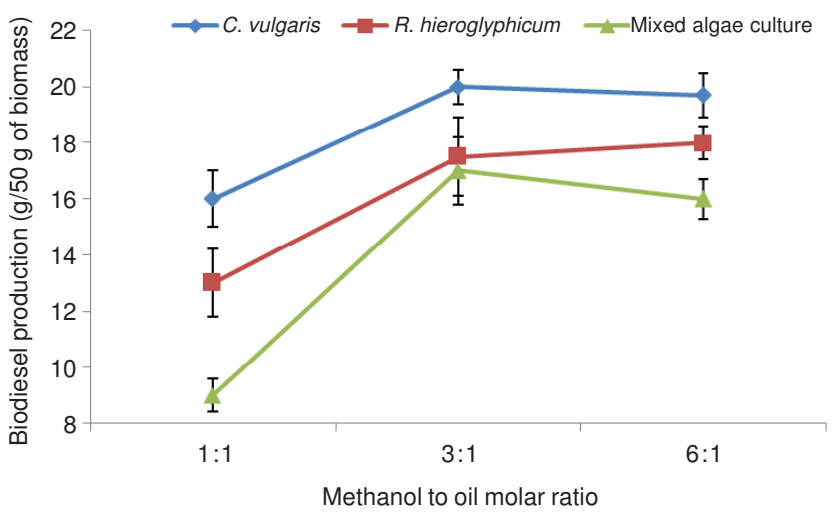

Fig. 4. Effect of methanol to oil ratio on biodiesel production from fifty grams of $C$. vulgaris, $R$. hieroglyphicum and mixed algae culture

Residual product of transesterification reactions: Transesterification of $C$. vulgaris derived algal oil was carried out with all four selected catalysts and residual triglycerides percentage was measured after every $20 \mathrm{~min}$. It was observed from the results that initially the transesterification process was slow in all reaction flasks but comparatively rapid in reaction flask containing $\mathrm{NaOH}$ as catalyst and after $1 \mathrm{~h}$ of reaction less residual product was found in reaction flask containing $\mathrm{Na}$ as catalyst. Production of byproducts became constant in reaction flasks except in a flask containing sulphuric acid as catalyst because reaction was slower in that flask and it gave maximum yield of biodiesel after $80 \mathrm{~min}$ (Fig. 5). The conversion of oil to biodiesel increases with increase in reaction time. Ma et al. ${ }^{28}$ studied the effect of reaction time on transesterification of beef tallow with methanol and it was observed that initially the reaction was slower till $5 \mathrm{~min}$ and it increased gradually with maximum methyl esters yield after $15 \mathrm{~min}$.

Effect of catalysts concentration in transesterification reaction: Different concentration $(0.5,1.0$ and $1.5 \%)$ of selected acid and basic catalysts were prepared and used for transesterification of algal oil extracted from C. vulgaris. A $50 \mathrm{~g}$ of oil extracted from selected algae was used for this reaction and yield of methyl ester was determined. Results indicated that yield of biodiesel was less at $0.5 \%$ and it was noted to be maximum at $1 \%$ after that it became constant with all the selected catalysts (Table-1). Al-Widyan and Al-Shyoukh ${ }^{29}$ used four levels of the catalyst concentration $(0.5,1.0,1.5$ and $2.25 \mathrm{M})$ in their experiments and found that increase in catalyst concentration resulted significant reduction in the reaction time. 


\begin{tabular}{|c|c|c|c|c|c|c|c|c|c|c|c|c|}
\hline \multirow{3}{*}{ Algal species } & \multicolumn{11}{|c|}{$\begin{array}{l}\text { TABLE-1 } \\
\text { PER CENT BIODIESEL PRODUCTION FROM DRIED ALGAL BIOMASS } \\
\text { USING DIFFERENT CONCENTRATIONS OF VARIOUS CATALYSTS }\end{array}$} & \\
\hline & \multicolumn{3}{|c|}{$\mathrm{Na}$} & \multicolumn{3}{|c|}{$\mathrm{NaOH}$} & \multicolumn{3}{|c|}{$\mathrm{KOH}$} & \multicolumn{3}{|c|}{$\mathrm{H}_{2} \mathrm{SO}_{4}$} \\
\hline & $0.5 \%$ & $1.0 \%$ & $1.5 \%$ & $0.5 \%$ & $1.0 \%$ & $1.5 \%$ & $0.5 \%$ & $1.0 \%$ & $1.5 \%$ & $0.5 \%$ & $1.0 \%$ & $1.5 \%$ \\
\hline \multirow[t]{2}{*}{ C. vulgaris } & 32.9 & 47.7 & 48.2 & 27.1 & 44.2 & 46.8 & 26.2 & 45.7 & 46 & 26 & 47.6 & 47.2 \\
\hline & \pm 0.9 & \pm 0.08 & \pm 1.0 & \pm 2.8 & \pm 2.1 & \pm 0.8 & \pm 4.2 & \pm 2.0 & \pm 1.7 & \pm 2.2 & \pm 1.3 & \pm 2.3 \\
\hline \multirow[t]{2}{*}{ R. hieroglyphicum } & 29 & 46.2 & 47.7 & 26.1 & 43.3 & 44.9 & 28.5 & 44.2 & 45.7 & 29 & 46.3 & 46.7 \\
\hline & \pm 1.3 & \pm 0.5 & \pm 1.4 & \pm 1.9 & \pm 3.1 & \pm 1.3 & \pm 2.3 & \pm 2.7 & \pm 0.7 & \pm 1.1 & \pm 1.0 & \pm 1.2 \\
\hline Mixed algae culture & $\begin{array}{l}30.1 \\
\pm 2.0\end{array}$ & $\begin{array}{c}47 \\
\pm 0.7\end{array}$ & $\begin{array}{l}46.2 \\
\pm 1.7\end{array}$ & $\begin{array}{c}30 \\
\pm 1.5\end{array}$ & $\begin{array}{r}45.8 \\
\pm 1.3\end{array}$ & $\begin{array}{r}46.3 \\
\pm 2.1\end{array}$ & $\begin{array}{c}28 \\
\pm 1.9\end{array}$ & $\begin{array}{l}45.2 \\
\pm 1.5\end{array}$ & $\begin{array}{l}45.2 \\
\pm 0.8\end{array}$ & $\begin{array}{l}28.1 \\
\pm 0.7\end{array}$ & $\begin{array}{l}47.1 \\
\pm 1.2\end{array}$ & $\begin{array}{l}46.2 \\
\pm 0.5\end{array}$ \\
\hline
\end{tabular}

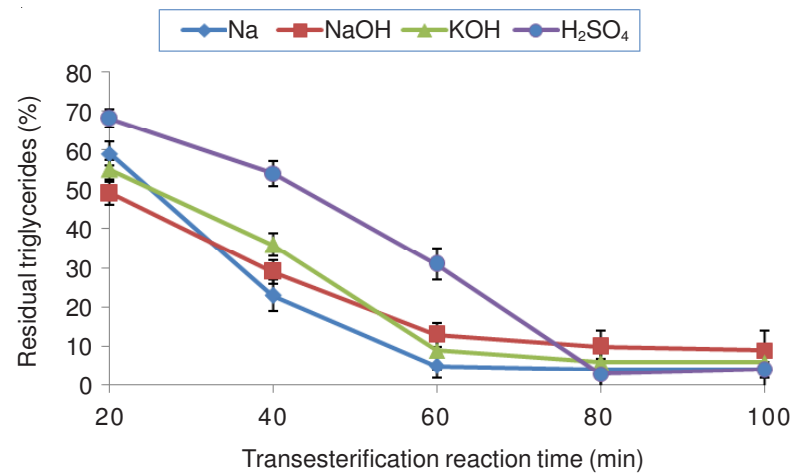

Fig. 5. Percentage of residual triglycerides by changing reaction time of transesterification

Yield of biodiesel: Biodiesel was produced from oil extracted from biomass of $C$. vulgaris using various catalysts with concentration level of $1 \%$. It was noted that sodium metal gave maximum yield followed by sulphuric acid. Sodium hydroxide gave lesser yield (Fig. 6) as soap formation occurred during transesterification process. Previous experiments also proved that acid catalyst were useful for transesterification of high free fatty acids feedstocks but their reaction rates are very slow $^{30}$ while alkali catalysts like sodium hydroxide and potassium hydroxide are suitable for vegetable oil and animal fats, respectively ${ }^{31}$.

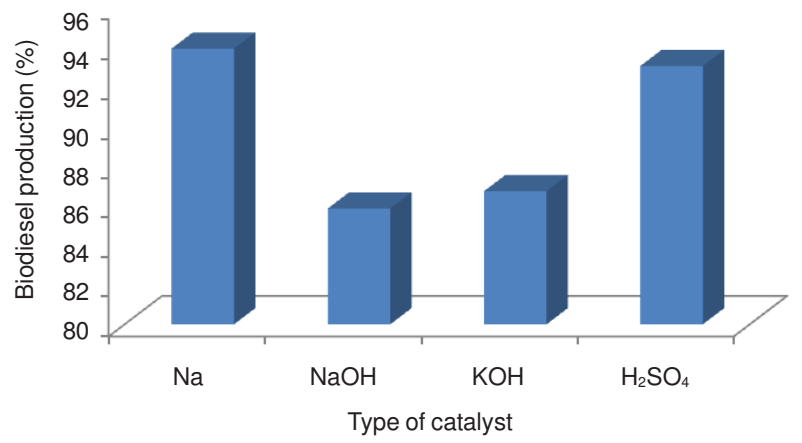

Fig. 6. Catalytic effect on per cent yield of biodiesel from algal oil
Characterization of biodiesel produced from algal oil: Oil extracted from algae generally consists of high degree of unsaturation as compared to vegetable oil ${ }^{32}$. When biodiesel was produced from algal oil and glycerin layer was separated then it was necessary to clean the biodiesel phase by employing phosphoric acid solution at $5 \% \mathrm{w} / \mathrm{w}$. Equal amount of acid solution and biodiesel were kept in settling vessel and mixed to remove residual glycerin and other impurities. After few minutes the cleaned biodiesel was deposited in a new vessel for analysis. The fuel properties of biodiesel were assessed by measuring its kinematic viscosity, flash point, specific gravity, cetane number, acid number and water contents. Viscosity is a very important property of fuels as it effects the fluidity of fuel in low temperature. Values of viscosity, flash point and density decreases during transesterification reaction. Pure biodiesel has higher flash point as compared to diesel fuel which makes this a safer fuel to handle and store near a potential ignition source. Inadequate cetane numbers result in poor ignition quality and delay, not normal combustion. Methyl esters also contain some water on it, which has negative effects on its yield. However the values of these parameters in the current study were within or near the limits of ASTM standards (Table-2) so it can be used as a fuel in vehicles.

\section{Conclusion}

Increasing prices and rapidly depleting resources of fossil fuel force researcher to produce renewable fuels. Biodiesel in this scenario can be a good alternative of fossil fuels but currently its price of production is high. This high price can be reduced by selecting cheap raw material and suitable process of production. In this study extraction of oil and its transesterification with various catalysts was carried out from biomass of different species of algae with suitable solvent. It was observed from the results that oil content of $C$. vulgaris was higher than $R$. hieroglyphicum and mix algae culture as maximum oil was extracted from this species using hexane as a solvent. Efficiency of $\mathrm{Na}$ metal and $\mathrm{H}_{2} \mathrm{SO}_{4}$ catalysts was quite similar but rate of reaction was slower with $\mathrm{H}_{2} \mathrm{SO}_{4}$ as compared

\begin{tabular}{lcccccc}
\multicolumn{7}{c}{ TABLE-2 } \\
\cline { 2 - 5 } & QUALITY OF BIODIESEL PRODUCED USING VARIOUS CATALYSTS \\
\hline \multicolumn{1}{c}{ Properties of biodiesel } & $\mathrm{Na}$ & $\mathrm{NaOH}$ & $\mathrm{KOH}$ & $\mathrm{H}_{2} \mathrm{SO}_{4}$ & ASTM D-6751-02 & Standards \\
\hline Density at $15^{\circ} \mathrm{C}(\mathrm{kg} / \mathrm{L})$ & 0.87 & 0.901 & 0.883 & 0.867 & $0.86-0.9$ \\
Kinematic viscosity at $37.8^{\circ} \mathrm{C}\left(\mathrm{mm}^{2} / \mathrm{s}\right)$ & 5.2 & 4.8 & 5.3 & 5.0 & $1.9-6.0$ & $>130$ \\
Flash point $\left({ }^{\circ} \mathrm{C}\right)$ & 145 & 139 & 143 & 147 & 0.88 & $>47$ \\
Specific gravity at $28^{\circ} \mathrm{C}(\mathrm{g} / \mathrm{mL})$ & 0.916 & 0.924 & 0.931 & 0.91 & 0.8 max. \\
Cetain number $(\mathrm{min})$ & 53 & 51 & 49 & 50 & 0.05 max \\
Acid number $(\mathrm{mg} \mathrm{KOH} / \mathrm{g})$ & 0.37 & 0.41 & 0.39 & 0.45 & - \\
Water contents $(\% \mathrm{vol})$ & 0.04 & 0.09 & 0.13 & 0.06 & 15971.6 & - \\
Calorific value $(\mathrm{gross})(\mathrm{BTU} / \mathrm{Lb})$ & 17712.8 & 12725.7 & 13757.5 & & & \\
\hline
\end{tabular}


to Na metal. Maximum biodiesel yield was obtained with $1 \%$ concentration of each catalyst. Biodiesel properties were comparable with ASTM standards hence it can be used as an alternative fuel instead of fossil fuels.

\section{ACKNOWLEDGEMENTS}

The authors acknowledged Government College University, Lahore for providing funding for the current study. The research work was carried out in laboratories of Sustainable Development Study Centre GC University Lahore, Southern Electric Power Company Limited Lahore and Pakistan Council of Scientific and Industrial Research, Lahore, which were equipped with all the necessary equipments for this study. The authors also acknowledged Mr. Tariq Rasheed and Director, Punjab Fisheries Department for providing algal samples. Special thanks are extended to Mr. Tahir Sattar, General Manager Operation \& Electrical and Ikram Hussain Arain, Chief Chemist for providing testing facilities at Southern Electric Power Company Limited, Lahore.

\section{REFERENCES}

1. P. Greg, Biodiesel: Growing a New Energy Economy, Foreword by B McKibben, United States, edn. 2 (2008).

2. H.E. Hoydoncx, D.E. De Vos, S.A. Chavan and P.A. Jacobs, Topic Catal., 27, 83 (2004)

3. A. Demirbas, Biodiesel: A Realistic Fuel Alternative for Diesel Engines, Springer Verlag, edn. 1, X, 208 p. 63 (2008).

4. G. Anastopoulos, E. Lois, A. Serdari, F. Zanikos, S. Stournas and S. Kalligeros, Energy Fuels, 15, 106 (2001)

5. A.S. Carlsson, J.B. van Beilen, R. Moler and D. Clayton, Micro and Macro Algae: Utility for Industrial Application. EPOBIO Project, University of New York (2007.

6. S.A. Khan, Rashmi and M.Z. Hussain, Renewable and Sustainable Energy Reviews, New Delhi, India (2009).

7. J.N. Rosenberg, G.A. Oyler, L. Wilkinson and M.J. Betenbaugh, Curr Opin. Biotechnol., 19, 430 (2008).
8. J. Sheehan, T. Dunahay, J. Benemann and P. Roesler, A Look Back at the US Department of Energy's Aquatic Species Program-Biodiesel from Algae, National Renewable Energy Program (1998).

9. Y. Chisti, Biotechnol. Adv., 25, 294 (2007).

10. D. Samios, F. Pedrotti, A. Nicolau, Q.B. Reiznautt, D.D. Martini and F.M. Dalcin, Fuel Process. Technol., 90, 599 (2009).

11. A.B.M.S. Hossain and M.A. Mazen, Aust. J. Crop Sci., 4, 550 (2010).

12. A. Widjaja, C. Chien and Y. Ju, J. Taiwan (Chin) Inst. Chem. Eng., 40, 13 (2009).

13. M. Letellier and H. Budzinski, Analysis, 27, 259 (1999).

14. X. Lang, A.K. Dalai, N.N. Bakhshi, M.J. Reaney and P.B. Hertz, Bioresour. Technol., 80, 53 (2001).

15. M. Charoenchaitrakool and J. Thienmethangkoon, Fuel Process. Technol., 92, 112 (2011)

16. X. Miao and Q. Wu, Bioresour. Technol., 97, 841 (2006).

17. K. Vijayaraghavan and K. Hemanathan, Energy Fuels, 23, 5448 (2009).

18. M.Y. Raie, Oil, Fats and Waxes, National Book Foundation, Islamabad, Pakistan, GNE-16760, edn. 1 (2008).

19. Y. Chisti, Eng. Manage. J., 5, 261 (2006).

20. C. Jimenez, B.R. Cossio and F.X. Niell, Aquaculture, 221, 331 (2003).

21. N.M. Verma, S. Mehrotra, A. Shukla and B.N. Mishra, Afr. J. Biotechnol., 9, 1402 (2010).

22. R. Harun, M. Singh, G.M. Forde and M.K. Danquah, Renew. Sust. Energ. Rev., 14, 1037 (2010)

23. A. Banerjee, R. Sharma, Y. Chisti and U.C. Banerjee, Crit. Rev. Biotechnol., 22, 245 (2002).

24. Y. Li, M. Min, Q. Kong, L. Wang, Y. Chen, P. Chen, G.C. Zittelli, L. Rodolfo, N. Biondi and M.R. Tredici, Aquaculture, 261, 932 (2006).

25. T. Mutanda, D. Ramesh, S. Karthikeyan, S. Kumari, A. Anandraj and F. Bux, Bioresour. Technol., 102, 57 (2011).

26. J.V. Gerpen, Fuel Process. Technol., 86, 1097 (2005).

27. L.C. Meher, D.V. Sagar and S.N. Naik, Renew. Sustain. Ener. Rev., 10, 248 (2006)

28. F. Ma, L.D. Clements and M.A. Hanna, Am. Soc. Agric. Eng., 41, 1261 (1998).

29. M.I. Al-Widyan and A.O. Al-Shyoukh, Bioresour. Technol., 85, 253 (2002).

30. B.H. Um and Y.S. Kim, J. Ind. Eng. Chem., 15, 1 (2009).

31. G. Huang, F. Chen, D. Wei, X. Zhang and G. Chen, Appl. Energ., 87, 38 (2010).

32. L. Rodolfi, G.C. Zittelli, N. Bassi, G. Padovani, N. Biondi, G. Bonini and M.R. Tredici, Biotechnol. Bioeng., 102, 100 (2009). 